\title{
Bertrand Russell's missing free trade manuscripts
}

\author{
by Richard A. Rempel
}

EARLY IN 1904 Russell gave a number of lectures defending free trade against Joseph Chamberlain's campaign for tariff reform. We know of these lectures from fragmentary references in local London and national newspapers as well as from correspondence with Russell's aunt, the Hon. Agatha Russell, Lucy Martin Donnelly and others. The lectures meant a great deal to him and were highly regarded by a number of very able people involved in public affairs. ${ }^{\prime}$ The Russell Editorial Project will soon be advancing to Volume XII, Politics and Religion, 1902-14, where the lectures would be printed. Unfortunately, we do not have the texts. Their discovery is, therefore, a matter of increasing urgency.

The first substantial clue to the existence of the lectures was a press cutting in the Russell Archives from an unidentified newspaper announcing that the Hon. Bertrand Russell would soon be giving six lectures for the newly organized Free Trade Educational Committee. The lectures were to begin on Friday, 15 January, at the New Reform Club - which has been called the haven of "advanced" Liberals who had protested against Liberal Imperialist support of the Boer War. By examining the typeface and layout of the clipping I predicted that it came from the Daily News, the leading Radical newspaper in Britain with the largest circulation of any "liberal" paper in the English-speaking world. Inspection of a microfilm of the Daily News for 6 January 1904 showed that I was correct, and I uncovered other references on 14 and 27 to the agenda of the talks and on 13 February a summary of his penultimate speech at the New Reform Club.

I See my "From Imperialism to Free Trade: Couturat, Halévy and Russell's First Crusade", The 7ournal of the History of Ideas, 40 (July-Sept. 1979), 423-43. 
26 Russell, nos. 35-6 (Autumn-Winter 1979-80)

Unfortunately, perusal of other leading Liberal and Conservative papers provided little further evidence. Only the Liberal Westminster Gazette contained on 5 January 1904 a slight notice referring to his anticipated talks. The local press, with the exception of one reference for 20 January 1904 in the Paddington, Kensington and Bayswater Chronicle, was equally disappointing.

Russell's engagement diary for 1904 makes it clear that his series of six free-trade lectures was presented every Friday from 15 January to 19 February with possibly another talk at the Free Trade Union on Tuesday, 16 February. Moreover, both his diary and the Daily News reveal that he delivered three lectures in the Chelsea Town Hall and three talks in the Paddington Town Hall. As well he gave a speech at Deptford-a total of possibly fourteen lectures. A letter to Lucy Donnelly corroborates that he spoke on free trade at Deptford on 27 February to skilled workmen from the local branch of the Amalgamated Society of Engineers. ${ }^{2}$ And his diary contains cryptic references which indicate that he may have given more speeches in January and February-at Islington, Harrow, Barford, Marlow and Elstree.

From the correspondence of Logan Pearsall Smith to his sister, Mrs. Bernard Berenson, we are told that Russell's first talk at the New Reform Club was expertly given and well-received-one of many indications that, had he chosen, Russell might have become a first-rate economist. From Aunt Agatha, in a letter of 10 January, we know that he sent a syllabus of his New Reform Club talks to her for her scrutiny. ${ }^{3}$ But so far neither the syllabus nor any manuscripts for his obviously rigorously developed speeches have been uncovered.

For a number of reasons Kenneth Blackwell and I think it very likely that Russell wrote out these free trade lectures. He most certainly wrote out the penultimate lecture since the Daily News of 13 February noted that, in his absence, Alys Russell read the paper to the audience. Furthermore, we know that it was Russell's practice at this time carefully to write out his lectures on any subject. Judging from the high quality of his published free trade articles, it is most unlikely that he spoke without a carefully composed text. Russell, it must be emphasised, was no dabbler in free trade theory. For the arguments in the three articles (one of which extends to 12,000 words) and four letters to the editor are set out with a rigour equal to that of economists as distinguished as Alfred Marshall. Finally, remarks to many of his correspondents that he had completely given

${ }^{2}$ The Autobiography of Bertrand Russell, I (London: Allen \& Unwin, 1967), p. 171.

${ }^{3}$ Ibid., p. 191. up philosophy in the period December 1903 to early March 1904, imply that he approached his free trade crusade so seriously, and with so much preparation, that it is improbable that he would have spoken "off the cuff".

To attempt to unearth the manuscripts and syllabus an extensive search was mounted and a ranging set of inquiries launched. Mrs. Barbara Halpern, grand-niece to Alys Russell and holder of her papers, was most helpful in allowing me to see all the relevant material now in her custody. But neither my search nor her continuing vigilance has led to any success. The Archivist wrote Mr. Hallam Tennyson, the son of the Secretary of the Free Trade Educational Committee, Miss Ivy Pretious. She was significant not only because of her official position but also because Russell was particularly fond of her and concerned that she not marry Reginald McKenna, a rich banker and later Liberal cabinet minister under Asquith. Mr. Tennyson informed the Archivist that no documents relating to free trade could be found in her papers. A professional historian and former colleague, Dr. Brian O'Farrell, kindly consented to sift all the materials of the Free Trade Union and of any other free trade organizations deposited in the British Museum. His efforts, alas, turned up no Russell material. I both wrote to the librarian of the Reform Club and visited that library-all to no avail. The New Reform Club disappeared years ago and no one seems to know what happened to its records. Finally, I also visited the premises of the erstwhile Free Trade Union, which is now an organization for the greater taxation of land values, free trade now being completely out of fashion. The librarian was most helpful, but neither of us could turn up anything relevant. I am thus hoping that this note will stimulate further research for the lost free-trade manuscripts on the part of any reader who is interested and has any ideas as to their whereabouts. The recovery of these manuscripts and the syllabus should strengthen my claim that Russell, had he chosen, could have been an important economic theorist. More important, the documents would tell us more about Russell as a public figure increasingly identified with the ideas of the New Liberals-who conceived the intellectual basis of the Liberal Government's social reforms during 1906-14.

Appended are the texts of the announcement of Russell's lectures and the sole summary that has come to light, as well as a bibliography of Russell's free trade publications.

Department of History

McMaster University 
(1) Announcement, Daily News, London, 6 Jan. 1904, p. 16, col. 1.

The first lectures of the newly-organized Free Trade Educational Committee, to which we refer in another column, will be delivered by the Hon. Bertrand Russell, beginning on Friday, January 15th, at 6 p.m., at the New Reform Club, 10, Adelphi-terrace, Strand. Tickets of admission, for which no charge is made, will be sent on application to Miss Pretious, hon. secretary, at the above address, together with a full syllabus of these lectures.

The lecturer, who is the brother and heir of Earl Russell, of agnostic, Radical, automobile, and other fame, is probably the deepest thinker at present standing next-door to a peerage. $\mathrm{He}$ has held a Fellowship at Trinity College, Cambridge, where he had a distinguished undergraduate career, and has published works on philosophy, geometry, mathematics, and politics. His "Principles of Mathematics" appeared last year.

(2) Summary, Daily News, London, 13 Feb. 1904, p. 10, col. 6.

\section{"DUMPING" ON THE COLONIES}

At the Reform Club, Adelphi, last night, the Hon. Mrs. Bertrand Russell read a paper by her husband on preferential tariffs.

In the course of this he said that if $\mathrm{Mr}$. Chamberlain took the same view about Free Trade when he went on his tour to the Colonies as he did now he would have to talk to the Colonists somewhat in the following strain: "Gentlemen,-We in England, awakened at last from our Cobdenite nightmare, have discovered that imports of manufactures are the greatest curse a nation can endure. We therefore, having learned to think Imperially, and having equal regard for all parts of his Majesty's dominions, except India, South Africa, and other places, invite you, the self-governing Colonies, to take the burden of unemployment and starvation upon yourselves, in order that we may practise upon you the dumping which we are no longer going to tolerate from foreigners."

Mr. Chamberlain's proposals, Mr. Russell contended, would lead to disruption of the empire, the enmity of foreign nations, and the risk of a league of all the Powers that desired England's overthrow.
(3) Russell's free trade publications (taken from Blackwell and Ruja's unpublished bibliography)

THE TARIFF CONTROVERSY. Edinburgh Review, Lon., 199 (Jan. 1904), 169-96.

Review of Joseph Chamberlain, Imperial Union and Tariff Reform; Memoranda, Statistical Tables and Charts prepared in the Board of Trade with reference to various matters bearing on British and Foreign Trade and Industrial Conditions; W. J. Ashley, The Tariff Problem; the Tariff Reform League, A Short Handbook for Speakers and Students of the Policy of Preferential Tariffs; and A.C. Pigou, The Riddle of the Tariff. Unsigned. Verified as Russell's through the editor's notebooks, in a letter of 29 Nov. 1966 to Blackwell from Longmans, Green and Co. The editor, Arthur Elliot, in a letter dated Dec. 1903 by Russell, congratulated him on the article and referred to his "few alterations" in proof. The issue of the journal was to be published on $15 \mathrm{Jan} .1904$.

LITERATURE OF THE FISCAL CONTROVERSY. Independent Review, Lon., 1 (Jan. 1904), 684-8.

Review of W.J. Ashley, The Tariff Problem, and A.C. Pigou, The Riddle of the Tariff. The British Library copy of this issue is datestamped 31 Dec. 1903.

MR. CHARLES BOOTH ON FISCAL REFORM. Spectator, Lon., 92 (16 Jan. 1904), 83-4.

Letter to editor.

Old AND NEW PRoteCtionism. Spectator, Lon., 92 (23 Jan. 1904), 125-6.

Letter to editor, signed "A Correspondent". Russell is identified as the author in the Spectator's account books.

InTERNATIONAL COMPETITION. Spectator, Lon., 92 (30 Jan. 1904), 180.

Letter to editor.

Mr. CHARLES BOOTH'S PROPOSALS FOR FISCAL REFORM. Contemporary Review, Lon., 85 (Feb. 1904), 198-206.

On Booth's article, National Review, Lon., 42 (Jan. 1904), 686ff .

MR. GERALD BALFOUR ON COUNTERVAILING DUTIES. Westminster Gazette, Lon., 10 Feb. 1904, p. 2.

Letter to editor. 